\title{
Credibility of Celebrity Endorsement and Buying Intentions an Evidence from Students of Islamabad, Pakistan
}

\author{
Naveed Ahmed ${ }^{1, *}$, Omer Farooq $^{2}$, Junaid Iqbal ${ }^{3}$ \\ ${ }^{1}$ Faculty of Management Sciences, National College of Business Administration, Lahore, Pakistan \\ 2Bahaudin Zakariya University, Multan, Pakistan \\ ${ }^{3}$ Muhammad Ali Jinnah University, Islamabad, Pakistan \\ *E-mail address: Naveed_8989@yahoo.com
}

\begin{abstract}
Celebrity Endorsement has become one of the important tools in advertisement persuading customers. No study has been yet conducted in Pakistan to measure the impact of credibility of celebrity on the buying intentions of customers. This paper investigates the credibility of celebrity endorser influence on consumers buying intention and also whether the experience of celebrity with the usage of endorsed product matters to consumers or not. For this purpose Regression tests are used and questionnaire was distributed to respondents who were university students/scholars. Results show that the in celebrity endorsement, credibility of endorsing celebrity matters for the consumer before the endorsed product also the experience of the celebrity with that product usage. Companies using celebrity endorsement strategy for their promotion must carefully select the endorsing celebrity with relatively high credibility.
\end{abstract}

Keywords: Celebrity endorsement; purchase intentions; youths of Pakistan; university students

\section{INTRODUCTION}

Due to cut throat competition companies use advertisement as most effective and bombardment tool to gain the competitive advantage. As celebrities are largely connected to public so celebrity endorsement is thought to be the best tool of advertisement to target maximum audience.

The product endorsed by celebrity can be transferred into more favorable attitude and product evaluation by the consumers (Dean \& Baswas, 2001). Its impact on financial returns is significant and helps to get competitive advantage (Erdogan, 1999). In America, $25 \%$ companies use celebrities in their ad due to its significance (Money, Shimp et al. 2006). Audience show interest in the endorsed product, an expert and consumer endorsement both increase audience attitude towards the product (Wang, 2005 ),

These factors prove the importance of celebrity but there can be others factors also that can alter the effectiveness of celebrity like the match between the product endorsed and celebrity (Till \& Shimp, 1998). 
McCracken (1989) defines Celebrity endorsement as: "Any individual who enjoys public recognition and who uses this recognition on behalf of a consumer good by appearing with it in an advertisement". If a company wants to create an image for its product or service then celebrity endorsement is the most effective and highlighted which can influence the customer. The combination of celebrity with brand should be according to the interest of target audience (Till, 1998). Agrawal and Kamakura (1995) concluded that the advertisements using celebrity is more effective than the advertisements using non-celebrity which shows a great contrast between celebrity and non-celebrity. There has been a diversified work of researchers regarding celebrity like effectiveness of celebrity, the positive and negative aspects of celebrity endorsement (Till \& Shimp, 1998); Profitability of celebrity endorsement (Amadi, 2005); celebrity endorsement and purchase intentions (Kamins, Brand et al. 1989); Fitting of celebrity with the endorsed product (Gwinner \& Eaton, 1999; Till \& Busler, 2000) the relationship of product differentiation and endorser (Busler, 2002); association of celebrity and its effectiveness (Daneshvary \& Schwer, 2000); and celebrity attractiveness, credibility, and trustworthiness (Ohanian, 1990; Rex, 1997).

(Harmon \& Coney, 1982) found that Greater credible resource of communication is more influential than less credible resource and it draws more constructive purchase behavior, it is very much necessary to use very credible resource to encourage the brand switching. The less credible source is more influential then more credible source When the audiences are previously positively disposed to the message so less credible source is some time much important than high credible resource (Sternthal, Dholakia et al. 1978). It has been confirmed that credibility of the commercial and endorser increases willingness to buy (Goldsmith, Lafferty et al. 2000; Shimp, 2000; Zahaf and Anderson, 2008).

People are star-struck by film stars, cricketers, politicians and national heroes. Why? The 170 million people are in love with celebrities because the matching principal, admiration, comfort and familiarity compel them to watch the celebrities in the ads. Pepsi got top position in beverages industry of Pakistan by using $90 \%$ sports celebrities in their ad and the massive $500 \%$ increment of sales of Telenor (talkshawk Package) proves the significance of celebrities in Pakistan (Khan, 2009). But here we are checking the credibility of celebrity in Pakistan because here people either they response like European or Canadian culture (Zahaf \& Anderson, 2008; Nadeem Iqbal, et.al, 2014 ) or differently.

\section{1. Literature Review}

[After reviewing the celebrity endorsement, selection criteria of celebrity, credibility of celebrity with the help of (Ohanian, 1990) Model and its impact on the consumer intentions to buy.]

In the development of promotional program, it's necessary to adopt such type of strategy for advertisement in which the Main focus should be the communication of distinctiveness and newness of the product to shape the positive attitude and enhanced purchase intentions towards brand (Lafferty \& Goldsmith, 2004). There are different entities which can influence the purchase intentions of the public that can be an expert, celebrity, whether an association or an endorser expertise (Daneshvary \& Schwer, 2000). The celebrity is an eminent personality who enjoys public recognition and uses that recognition in order to persuade the customers (McCracken, 1989). The celebrities can better influence the desires and feelings of target audience than the non-celebrity. (Till, 1998). It's successful for building brand equity with the increment of brand credibility and provide course of action for selecting an endorser. (Forouhandeh, Nejatian et al. 2011). The voice of celebrity creates an important role in TV or radio advertising in order to persuade the customer. (Leung, Kee et al. 1999). With voice the 
attractiveness of celebrities can also create a remembrance effect in the minds of customer. (Mohammad, Zoubi et al. 2011). The physical appearance and outlook of the endorser is dominant aspect for creating a match-up because the attractive endorser has positive effect on the enhancement in using product (Till \& Busler, 1998). The Likeness of attractive communicator is more than the unattractive communicator and its impact on the purchase intentions of people is more favorable. (Joseph, 1982)

It's more effective by using several celebrity endorsements. The level of matching between target audiences (gender-wise) and the celebrity endorser take part in the effectiveness of advertisement (hsu and McDonald, 2002). The selection of celebrity is not only the solution of problem but the realization of people with the argument of celebrity (Silvera \& Austad, 2004).

According to different researchers the criteria for the selection of celebrity is different. Some of the different criteria are:

Celebrity /Audience Match-up (Solomon, Ashmore et al. 1992) Celebrity / Brand Match-up (Liu, Huang et al. 2007; Liu, 2011), Credibility of celebrity (Horai, Naccari et al. 1974), cost related to the celebrity (Powell, Jonathan Hardy et al. 2009), Working Ease / Difficulty (Tyler and Bennett, 2009), Saturation factor (Veen, 2004). The trouble factor in face recognition (Peli, Lee et al. 1994), Risk associated with the celebrity (Havlena \& DeSarbo, 1991), success of a celebrity (Turner, 2006).

The consumer willingness to purchase is complicatedly related to the credibility of the celebrity, their understanding according to the knowledge about celebrity, the pleasant appearance, their reputation as well as celebrity resemblance to product (Sliburyte, 2009). But according (Hovland \& Weiss, 1951) to there is no difference in provision of factual information either by a credible person or non-credible person. The systematic impact of source credibility on thinking generation is more on attitude at the time of their early views. (Sternthal, Dholakia et al. 1978).

According to Ohanian (1990) there are different factors which affects the source credibility of the celebrity and proposed a model (that's our base model). There are three main determinants of source credibility which are attractiveness, experience and trust worthiness. Each determinant has different characteristics. We are taking experience with the moderating effect and investigating the impact of credibility of the celebrity on consumer willingness to buy. The model is as follow;

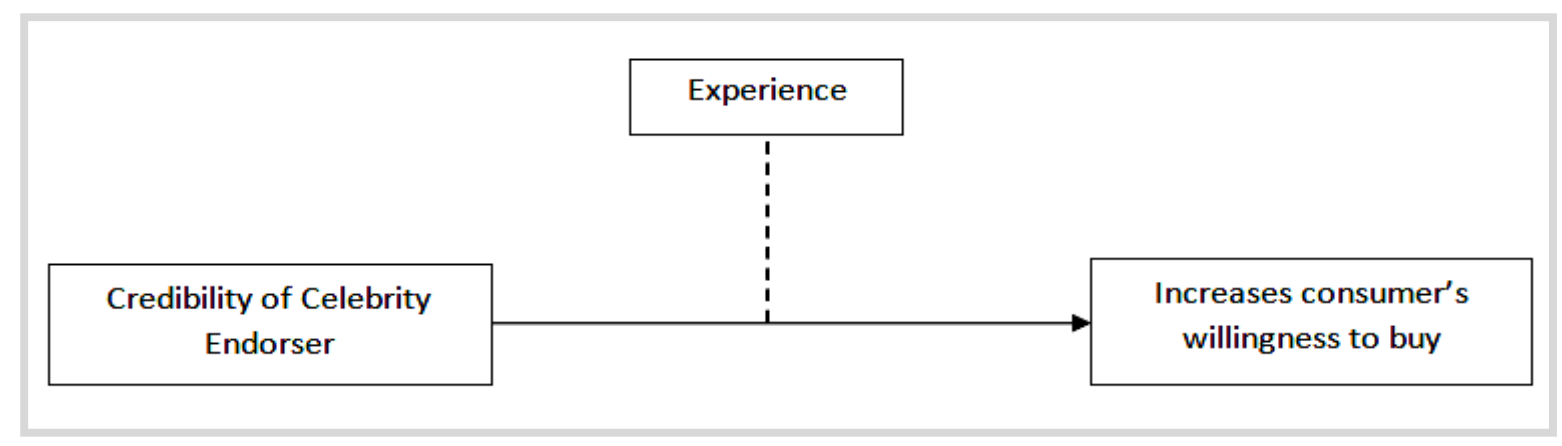

\section{2. Attractiveness}

The traditional concept that good appearance makes sense in people to purchase something (Reingen \& Kernan, 1993). The visual elements of an ad create a sense of 
attractiveness and develop a positive attitude towards purchase attention. (Clow, James et al. 2006). The works of many researchers prove that the outlook and physical attractiveness is a special element through which the effectiveness of celebrity is checked.

(Baker, CHurchill et al. 1977; Joseph 1982; Kahle and Homer, 1985; Winham \& Hampl, 2008) But according to Bower \& Landreth (2001) the highly attractive models are not so much effective in advertising often. There are many dimensions of attractiveness and which are difficult to determine, the attractiveness cannot be defined through a single dimension. (Caballero \& Solomon, 1984). The attractive faces are the best indication for influencing social judgments. (O'Doherty, Winston et al. 2003). The beauty and outlook is not only matter but the non-physical attributes also play an important role in the effectiveness of celebrity like achievements in sports, tact, intelligence (Kamins, 1990; Sliburyte, 2009) relating to the ethnic group of consumer (Deshpandé \& Stayman, 1994).

\section{3. Trustworthiness}

In the credibility ratings the trustworthiness is the most desirable by the customer because it's the intangible magic of the celebrity which works due to trust (Moynihan, 2004). The main components of the trustworthiness are reliability, Dependable, honesty, sincere and trustworthy. Mostly the youngsters are more dependable than the old ones because they want to follow the trend by the celebrities (Pandey, 2011). Anyone who can positively or negatively influence the consumer's attitude is called reference group and celebrities are the most reliable reference group (Escalas and Bettman, 2005). The women trust more on women celebrities and male on male celebrities (Sliburyte, 2009). As it was according to gender but at the different stages of consumer the level of trust and trustworthiness is same (Sutter and Kocher, 2007).

Companies can also get advantage of endorser high credibility which comes from high reputation, popularity, high public image and trustworthiness (Song, Chaipoopiratana et al. 2008).

\section{EXPERIENCE}

The products having low involvement and endorsed by an expertise having experience have a positive effect on intentions to buy by consumers (McGuire, 1985). Involvement in issue, (Cacioppo et al. 1981) the capacity of message to influence consumer, (Ratneshwar \& Chaiken, 1991) timing for behavioral response, (Dholakia \& Sterntha, 1977) timing of source recognition (Sternthal, Dholakia et al. 1978; Homer \& Kahle, 1990). According to (Zhang et al. 2011) the term "Fit" is intimately related with the term expertise as the athletes would be more successful for the products related to performance of an athlete in a specific game. Ohanian (1990) found that the experienced one performs the effective role in the celebrity endorsement and it increase the credibility of a celebrity endorser rather than the attractiveness and trustworthy.

According to (Pappu et al. 2011) the increased trust in brand has an indirect impact on the brand and increases the credibility and trust on brand. The companies also use the strategy of using many endorser at the same for a single product (like Mobilink in Pakistan) in order to increase the willingness to buy by customer (Jensen et al. 1994). The customers can switch with the greater intentions to buy, if the competitor is offering greater convenience and trust (Ngobo, 2004). The hypotheses are as follow: 
H1: Credibility of the celebrity increases willingness of consumers to buy.

H2: Credibility with the moderating effect of moderating experience of celebrity increases willingness to buy

\section{METHODOLOGY}

Research has been conducted to analyze the relationship of credibility of celebrity endorser and consumers intentions to buy. Sampling university students as their buying behavior disclose many patterns. Like what consumers perceive about the celebrity endorsement, whether it helps to recall the brand, improves the image of product, buying routine of university students, influence of credibility of celebrity persuading to buy a particular product.

We want to elaborate the cause and effect of credibility of celebrity matters to consumers to buy a product and later to analyze the influencing variable to this relationship.

Questionnaires were distributed to 110 students and were selected for study on volunteer basis. Respondents were from different fields of study so that we could have more generalized response than from business graduates only. Respondents were selected on the basis that if they use any telecom mobile phone services.

\section{RESEARCH DESIGN}

Questionnaire was provided to students, it contained a print advertisement of celebrity endorsing a product. Respondent was directed to view the print advertisement first and then to fill the questionnaire so that a more concentrated and involved response could be gathered. Respondents were segregated into two groups. First group was provided a questionnaire having a print ad of celebrity with high credibility while second group's questionnaire included the print ad of celebrity with relatively low credibility. Questionnaire was filled in the presence of experimenter and immediately returned immediately.

After viewing the advertisement respondents were asked to rate the credibility of celebrity on the 5-point scale provided by Ohanian (1990) for what they perceive celebrity is attractive, expert and trustworthy. Later section of questionnaire included the statements to measure the buying intentions of consumers influenced by the celebrity. For this measurement five point likert scale was used ranging from Strongly Agree to Strongly Disagree $(1=$ Strongly Agree, 2 = Agree, 3 = Neutral, $4=$ Disagree, $5=$ Strongly Disagree).

To verify the internal consistency all variables were tested to determine the structure of the data. Factor analysis facilitated that the constructs are right. Cronbach alpha of Credibility of Celebrity Endorser resulted 0.85, buying intentions 0.90 and the experience of celebrity with usage of product had 0.60 cronbach alpha. The measure of credibility was analyzed with the 5Point likert scale with $1=$ Strongly Disagree, $2=$ Disagree, $3=$ Neutral, $4=$ Agree, $5=$ Strongly Disagree. All measures are strongly correlated with each other. The reliability of the measures is checked by Cronbach's alpha and all are at the value of acceptability. The Cronbach's alpha of credibility of celebrity is 0.845 , experience 0.60 , and buying intentions is 0.894 . 


\section{Reliability Statistics of credibility}

\begin{tabular}{|c|c|}
\hline Cronbach's Alpha & N of Items \\
\hline .845 & 10 \\
\hline
\end{tabular}

\section{Reliability Statistics of buying intentions}

\begin{tabular}{|c|c|}
\hline Cronbach's Alpha & N of Items \\
\hline .894 & 11 \\
\hline
\end{tabular}

\section{Reliability Statistics of experience of celebrity}

\begin{tabular}{|c|c|}
\hline Cronbach's Alpha & N of Items \\
\hline .60 & 3 \\
\hline
\end{tabular}

\section{RESULTS}

Sample was selected randomly from population. Firstly discussing the demographics of respondents;

Table 1. Distribution of Gender.

\begin{tabular}{|c|c|c|}
\hline Variable of Gender & Frequency & Percentage \\
\hline Male & 76 & 69.1 \\
\hline Female & 34 & 30.9 \\
\hline Total & 100 & 100 \\
\hline
\end{tabular}

Table 1 shows male responded with high percentage of (69.1\%) and female with (30.9\%).

Table 2. Distribution of Age.

\begin{tabular}{|c|c|c|}
\hline Variable of Age & Frequency & Percentage \\
\hline $15-20$ years & 22 & 20.0 \\
\hline $21-25$ years & 71 & 64.5 \\
\hline 26-30 years & 12 & 10.9 \\
\hline Above 30 years & 5 & 4.5 \\
\hline Total & 110 & 100 \\
\hline
\end{tabular}

Table 2 shows age group of 21-25 years responded with highest percentage of $(64.5 \%)$, age group with 15-20 years on second with the percentage of (20\%), age group 26-30 years responded $(10.9 \%)$ and lastly above 30 years group at lowest with (4.5\% only). 
Table 3. Occupations of Respondents.

\begin{tabular}{|c|c|c|}
\hline Variable of Occupation & Frequency & Percentage \\
\hline Student & 78 & 70.9 \\
\hline Young Professional & 20 & 18.2 \\
\hline Businessmen & 8 & 7.3 \\
\hline Other & 4 & 3.6 \\
\hline Total & 110 & 100 \\
\hline
\end{tabular}

Table 3 exhibits that student with highest percentage (70.9\%), young professionals with (18.2\%), and part time business owners with $7.3 \%$ and other with lowest percentage $(3.6 \%)$. We have used two hypotheses in our research. The first one is about the relationship of credibility of celebrity and consumer willingness to buy. The other one is about the relationship of credibility of celebrity and consumer willingness to buy with the moderating effect of experience of celebrity.

We checked the validity of both of hypothesis with the help of descriptive statistics. We computed the mean and standard deviation of all the items. Credibility of celebrity shows the mean of 3.5418, which shows the evaluation about it great. The evaluation about the experience and buying intentions is median.

\begin{tabular}{|c|c|c|}
\hline Variables & Mean & Std. Deviation \\
\hline CB & 3.5418 & .76415 \\
\hline EX & 3.4121 & .89389 \\
\hline BI & 3.4529 & .84359 \\
\hline
\end{tabular}

H1: The credibility of celebrity has positive relation on the buying intentions of consumers.

$\mathrm{H} 2$ : The experience of celebrity about a produce moderates the effect of credibility of celebrity and its impact on buying intentions of consumer.

In analyzing the results of model we found that all proposed relationship did not got strong support from the results. The direct relationship between credibility of celebrity and the consumer willingness to buy shows significant with the value of .000 .

After controlling the effect of independent variable and creating the interaction term including the credibility of celebrity and moderator experience then the significant level is .457. Which shows there is negative relationship of moderating effect of experience. The R-Square change and unstandardized beta is in the table: 


\begin{tabular}{|c|c|c|c|c|c|}
\hline Model & $\begin{array}{c}\mathrm{R} \\
\text { Square }\end{array}$ & $\begin{array}{c}\text { R Square } \\
\text { Change }\end{array}$ & F Change & Level of Sig. & Beta \\
\hline 1 & .538 & .538 & 62.307 & .000 & .297 \\
2 & .540 & .002 & .558 & .457 & -0.059 \\
\hline
\end{tabular}

a. Predictors: (Constant), EX, CB
b. Predictors: (Constant), EX, CB, EXxCB

We measure here the moderating effect of experience of celebrity about a product on the consumer intentions to buy. Regression results shows that the respondents are not willing to buy a product with the moderating effect of experience of a celebrity due to not care of experience because the outlook and trust on celebrity is more important for the public.

\section{DISCUSSION}

The use of credible celebrity in the advertisement is suggested in the as a significant factor in the effective advertising. Yet there has been a little research in the field of credibility of celebrity in the advertising. Results of the study add to literature in many aspects. First, Celebrity Endorsement is important for the companies to capture the attention of their consumers because the audiences are influenced by the celebrities in willingness to buy. We testified that the credibility of the endorser matter to viewer/respondent/user/consumer to buy a particular product. This credibility not only influences the mind of consumers to purchase the product but also to develop a positive word of mouth regarding the brand being endorsed by the high credibility celebrity. Our results show that if the credibility of celebrity is high then it influences more to buy than a celebrity with relatively low credibility. The experience about a product is not necessary in the advertisement because audiences only care about the opinion of celebrity about the product. But it's true that their opinion acceptance strongly depends on the credibility of celebrity. So using a credible celebrity in the advertisement is goldmine for the companies for earning the market share, profits and revenues. Unlike the findings of Zahaf and Anderson (2008) credibility, in terms of attractiveness, trustworthiness and expertise, has significant importance when there is celebrity to endorse a product. Experience of Celebrity Endorser with the usage of endorse brand positively moderates the relationship of credibility of celebrity endorser and buying intentions. Consumers believe that if celebrity uses the endorsed product then it increases intentions to buy the endorsed product. This contradicts with the finding Zahf and Anderson (2008) and agrees with the finding of Kahle and Homer (1995) in terms of experience which matters consumers.

This study supports the findings of the Zahf and Anderson (2008) in terms of their determinants influencing the buying intentions of the consumers that are attractiveness, trustworthy, and experience. Experience does not really matters to the consumers because trustworthy and attractive celebrity can influence more the audiences. When the entertainment or sports celebrity is selected then their attractiveness and the trustworthiness are the first priorities of the companies. Our studies contradict the study of the Kahle and Homer (1995) 
that the experience of celebrity matters in the advertising. The moderating relationship of the celebrity in the effect of willingness to buy by the consumer is weak.

Companies uses the celebrities on the bases of the popularity in the public but the guarantee of success is not necessary in this type of advertising so the selection of celebrity is such phenomena in which the companies have to care about the credibility of celebrity because it is positively correlated with the consumer willingness to buy. So it's proved that if the celebrity is well known but not credible then he will not so much influence the consumer willingness to buy. It's clear when the company designs its promotion strategy for setting an image in the minds of consumer then hiring of celebrity should not be only work but the survey should be conducted for knowing about the most credible celebrity. Finally, using celebrity endorsers with high credibility can help consumers to remember the brand and can affect them to recall when they are at purchase store.

\section{1. Implications}

Our study adds to literature in the aspect mentioned above. In the case of managerial implications, the companies which use promotional strategies, particularly celebrity endorsement must be careful while selecting celebrity for endorsement because our study clearly shows that credibility of endorsers matters a lot for consumers. If the celebrity is well known but not credible then it will not affect consumers' willingness to buy the endorsed product. Company should design their promotional strategy after proper research that which celebrity is appropriate to endorse product according to their target audience, keeping the credibility factor in the mind.

\section{2. Future Direction}

Research study can be replicated for the other contexts. We conducted this study to find out the effect of credibility of celebrity on buying intentions, Furthermore this study can be conducted again with different variables like attractiveness of celebrity on of brand value, moderation with similarity and attractiveness of celebrity and with other variables. Different age groups can be tested for even generalized response.

\section{3. Limitation}

This study has been conducted within very short span of time. Small size of sample has been used and has been only tested within two cities Rawalpindi and Islamabad, Pakistan. Moderation has been tested with experience of celebrity only.

\section{References}

[1] Agrawal, J. and W. A. Kamakura (1995). "The Economic worth of celebrity endorder: An event study analysis." Journal of marketing 59: 56-62.

[2] Amadi, C. W. (2005). "Advertising expenditure anfd firm profitibility: An Investigation." Academy of Marketing Studies Journal 9: 3-19.

[3] Baker, M. J., G. A. CHurchill, et al. (1977). "The Impact of Physically Attractive Models on Advertising Evaluations." Journal of Marketing Research 14: 538-555.

[4] Bower, A. B. and S. Landreth (2001). "Is beauty best? Highs versus normally attractive models in advertising." Journal of Advertising 30: 1-11. 
[5] Braunstein-Minkove, J. R., J. J. Zhang, et al. (2011). "Athlete endorser effectiveness: model development and analysis." Sport, Business and Management: An International Journal 1: 93-114.

[6] Caballero, M. J. and P. J. Solomon (1984). "Effects of Model Attractiveness on Sales Response." Journal of Advertising 13: 17-23.

[7] Clow, K. E., K. E. James, et al. (2006). "The relationship of the visual element of an advertisement to service quality expectations and source credibility." Journal of Services Marketing 20: 404-411.

[8] Daneshvary, R. and R. K. Schwer (2000). "The association endorsement and consumers' intention to purchase." Journal of consumer marketing 17: 203-213.

[9] Dean, D. H. and A. Baswas (2001). "Third-Party organization endorsement of product; an advertising cue affecting consumer prepurchase evaluation of good and services." Journal of advertising Winter 2001; 30, 4: pg. 41.

[10] Deshpandé, R. and D. M. Stayman (1994). "A Tale of Two Cities: Distinctiveness Theory and Advertising Effectiveness." Journal of Marketing Research 31: 57-64.

[11] Dholakia, R. R. and B. Sterntha (Mar., 1977). "Highly Credible Sources: Persuasive Facilitators or Persuasive Liabilities?" Journal of Consumer Research 3: 223-232.

[12] Erdogan, B. Z. (1999). "Celebrity Endorsement: A Literature Review." Journal of Marketing Management 15: 291-314.

[13] Escalas, J. E. and J. R. Bettman (2005). "Self-Construal, Reference Groups, and Brand Meaning." Journal of Consumer Research 32: 378-389.

[14] Forouhandeh, B., H. Nejatian, et al. (2011). Determining advertising's efficiency: Celebrity endorsement versus non-celebrity models. 2nd International conference on business and economic research.

[15] Goldsmith, R. E., B. A. Lafferty, et al. (2000). "The Influence of Corporate Credibility on Consumer Attitudes and Purchase Intention." Corporate Reputation Review 3: 304-318.

[16] Gwinner, K. P. and J. Eaton (1999). "Building brand image through event sponsorship: The role of image transfer." Journal of Advertising 28.

[17] Harmon, R. R. and K. A. Coney (1982). "The Persuasive Effects of Source Credibility in Buy and Lease Situations." Journal of Marketing Research 19: 255-260.

[18] Havlena, W. J. and W. S. DeSarbo (1991). "On the Measurement of Perceived Consumer Risk." Decision Sciences 22: 927-939.

[19] Homer, P. M. and L. R. Kahle (1990). "Source Expertise, Time of source identification, and involvement in persuation: An elaboration processing perspective." Journal of advertising 19: 30-39.

[20] Horai, J., N. Naccari, et al. (1974). "The effects of expertise and physical attractiveness upon opinion agreement and liking." Sociometry 37: 601-606.

[21] Hovland, C. I. and W. Weiss (1951). "The Influence of source credibility on communication effectiveness " Public opinion quarterly winter: 635-650. 
[22] Hsu, C.-k. and D. McDonald (2002). "An examination on multiple celebrity endorser in advertising " Journal of Product \& Brand Management 2: 19-29

[23] Joseph, W. B. (1982). "The credibility of physically attractive communicators; a review." Journal of Advertising 11: 15-24.

[24] Kahle, L. R. and P. M. Homer (1985). "Physical Attractiveness of celebrity endorser: A socilal perspective." Journal of consumer research 11: 954-961.

[25] Kamins, M. A. (1990). "An Investigation into the "Match-up" Hypothesis in Celebrity Advertising: When Beauty May Only Skin Deep." Journal of Advertising 19: 4-13.

[26] Kamins, M. A., M. J. Brand, et al. (1989). "Two-Sided versus One-Sided Celebrity Endorsements: The Impact on Advertising Effectiveness and Credibility." Journal of Advertising 18: 4-10.

[27] Lafferty, B. A. and R. E. Goldsmith (2004). "How Influential are Corporate Credibility and Endorser Attractiveness When Innovators React to Advertisements for a New HighTechnology Product?" Corporate Reputation Review 7: 24-36.

[28] Leung, L. a. Kee, et al. (1999). "The effects of male celebrity voice-over and gender on product brand name recall, comprehension, and purchase intention." Atlantic Journal of Communication 7(1): 81-92.

[29] Liu, M. T. (2011). "Selecting a female athlete endorser in China." European Journal of Marketing 45: 1214-1235.

[30] Liu, M. T., Y.-Y. Huang, et al. (2007). "Relations among attractiveness of endorsers, match-up, and purchase intention in sport marketing in China." Journal of Consumer Marketing 24: 358-365.

[31] McCracken, G. (1989). "Who is celebrity endorser, Cultural foundation of endorsement process." Journal of Consumer Research 16: 310-321.

[32] Mohammad, O. A. Zoubi, et al. (2011). "The Effect of using Celebrities in Advertising on the Buying Decision "Empirical Study on Students in Jarash Private University" American Journal of Scientific Research (13): 59-70.

[33] Money, R. B., T. A. Shimp, et al. (2006). "Celebrity endorsement in Japan and the United states: Is negative information all that harmful ?" Forthcoming in Journal of Advertising Research 26.

[34] Moynihan, R. (2004). "The Intangible Magic of Celebrity Marketing." PLoS Medicine 1(1): 102-104.

[35] Ngobo, P. V. (2004). "Drivers of customers' cross-buying intentions." European Journal of Marketing 38 1129-1157.

[36] O'Doherty, J., J. Winston, et al. (2003). "Beauty in a smile: the role of medial orbitofrontal cortex in facial attractiveness." Neuropsychologia 41: 147-155.

[37] Ohanian, R. (1990). "Construction and Validation of a Scale to Measure Celebrity Endorsers' Perceived Expertise,Trustworthiness, and Attractiveness." Journal of Advertising 19: 39-52. 
[38] Pandey, V. K. (2011). "Impact of Celebrity Endorsement on Young Generation through TV Advertisement." VSRD International Journal of Business \& Management Research 1: $226-231$.

[39] Peli, E., E. Lee, et al. (1994). "Image enhancement for the visually impaired: the effects of enhancement on face recognition." Optical Society of America 11: 1929-1939.

[40] Petty, R. E., J. T. Cacioppo, et al. (1981). "Personal involvement as a determinant of arguement-Based persuation." Journal of personality and social psychology 41: 847-855.

[41] Powell, H., Jonathan Hardy, et al. (2009). The Advertising Handbook, Advertising Standards Authority.

[42] Ratneshwar, S. and S. Chaiken (1991). "Comprehension's Role in Persuation: The case of its moderating effect on the persuasive impact of source cues." Journal of Consumer Research 18.

[43] Reingen, P. H. and J. B. Kernan (1993). "Social Perception and Interpersonal Influence: Some Consequences of the Physical Attractiveness Stereotype in a Personal Selling Setting." Journal of Consumer Psychology 2: 25-38.

[44] Rex, M. (1997). "Source Expertise and Attractiveness of Celebrity Endorsers: a Literature Review." Cyber Journal of sport advertising.

[45] Shimp, T. A. (2000). Advertising Promotion: Supplemental Aspects of Integrated Marketing Communications. Fort Worth, TX., Dryden Press.

[46] Silvera, D. H. and B. Austad (2004). "Factors predicting the effectiveness of celebrity endorsement advertisements." European Journal of Marketing 38: 1509-1526.

[47] Sliburyte, L. (2009). "How celebrities can be used in advertising to the best advantage?" World Academy of Science, Engineering and Technology 58: 934-939.

[48] Solomon, M. R., R. D. Ashmore, et al. (1992). "The Beauty Match-up Hypothesis: Congruence between Types of Beauty and Product Images in Advertising." Journal of Advertising 21: 23-34.

[49] Spry, A., R. Pappu, et al. (2011). "Celebrity endorsement, brand credibility and brand equity." European Journal of Marketing 45: 882-909.

[50] Sternthal, B., R. Dholakia, et al. (1978). "The Persuasive Effect of Source Credibility: Tests of Cognitive Response." Journal of Consumer Research 4: 252-260.

[51] Sutter, M. and M. G. Kocher (2007). "Trust and trustworthiness across different age groups." Games and Economic Behavior 59: 364-382.

[52] Till, B. D. (1998). "Using celebrity endorsers effectively: lessons from associative learning." Journal of Product \& Brand Management 7: 400-409.

[53] Till, B. D. and M. Busler (1998). "Matching products with endorsers: attractiveness versus expertise." Journal of consumer marketing 15: 576-586.

[54] Till, B. D. and M. Busler (2000). "The Match-up Hypothesis: Physical Attractiveness, Expertise, and the Role of Fit on Brand Attitude, Purchase Intent and Brand Beliefs." Journal of Advertising 29: 1-13. 
[55] Till, B. D. and T. A. Shimp (1998). "Endorsers in advertising: The case of negative celebrity information." Journal of Advertising 27.

[56] Tripp, C., T. D. Jensen, et al. (1994). "The Effects of Multiple Product Endorsements by Celebrities on Consumers' Attitudes and Intentions." Journal of Consumer Research 20: 535-547.

[57] Turner, G. (2006). "The mass production of celebrity." International Journal of Cultural Studies 9: 157-165.

[58] Tyler, I. and B. Bennett (2009). "Celebrity Chav: Fame, Femininity and Social Class." European Journal of Cultural Studies 13.

[59] Wang, A. (2005 ). "The Effects of Expert and Consumer Endorsements on Audience Response." Journal of advertising research: 402-412.

[60] Winham, D. and J. S. Hampl (2008). "Adolescents report television characters do not influence their self-perceptions of body image, weight, clothing choices or food habits." Young consumers 9: 121-130.

[61] Zahaf, M. and J. Anderson (2008). "Causality effects between celebrity endorsement and the intentions to buy." Innovative Marketing 4(4): 57-65.

[62] Nadeem Iqbal, Naveed Ahmad, Zeeshan Haider, Sonia Anwar, International Letters of Social and Humanistic Sciences 5 (2014) 73-80.

[63] Nadeem Iqbal, Naveed Ahmad, Komal Javaid, International Letters of Social and Humanistic Sciences 6 (2014) 60-73.

[64] Nadeem Iqbal, Naveed Ahmad, Maira Abrar, Aisha Hassan, International Letters of Social and Humanistic Sciences 7 (2014) 31-43. 